\title{
Community Participation in Public Peace and Order in Imandi Village, East Dumoga Subdistrict, Bolaang Mongondow Regency
}

Jeane Mantiri 1,* (D), and Cynthia Maria Siwi 2

${ }^{1}$ Department of Public Administration, Faculty of Social Science,

Universitas Negeri Manado, 95618, Minahasa, North Sulawesi Province, Indonesia

2 Department of Public Administration, Faculty of Law, Social Science, and Political Science,

Universitas Terbuka, 15418, South Tangerang, Banten Province, Indonesia

*Corresponding Author: jeanelitha@unima.ac.id

\section{ARTICLE INFO}

Publication Info:

Research Article

How to cite:

Mantiri, J., E Siwi, C. M. (2020).

Community Participation in

Public Peace and Order in Imandi

Village, East Dumoga Subdistrict, Bolaang Mongondow Regency.

Society, 8(2), 761-771.

DOI: $10.33019 /$ society.v8i2.262

Copyright (c) 2020. Owned by Author(s), published by Society

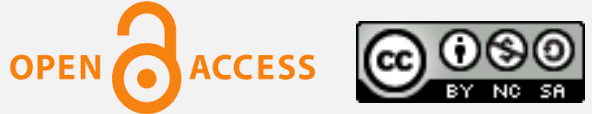

This is an open-access article.

\section{License: Attribution-}

NonCommercial-ShareAlike

(CC BY-NC-SA)

Received: November 12, 2020;

Accepted: December 28, 2020;

Published: December 31, 2020;

\begin{abstract}
This study aims to analyze and describe the public participation level and the factors supporting and inhibiting public participation in maintaining peace and order in Imandi Village. This research uses a descriptive qualitative research method. This research was located in Imandi Village, East Dumoga Subdistrict, Bolaang Mongondow Regency, North Sulawesi Province, Indonesia. The results showed that: 1) The Imandi Village community's participation is still not well implemented. Therefore, it will be better to maintain public peace and order in the village if it starts from individuals as small community units. It allows the realization of solidarity, which will significantly affect group members or community members in public peace and order implementation. 2) Efforts to motivate people to participate through Mapalus (mutual assistance activities) need leaders who can be role models. Village community leaders can be the key motivator in mutual assistance activities, but the government's participation is required. (3) The village government and its apparatus must continue to managing and fostering community members, especially in multicultural communities, to prevent the disruption of public peace and order.
\end{abstract}

\section{Keywords: Community Participation; Multicultural; Public Order; Public Peace; Solidarity}

Copyright (C) 2020. Owned by Author(s), published by Society. This is an open-access article under the CC-BY-NC-SA license. 


\section{Introduction}

A peaceful and orderly environment is the willingness of every community, which is one factor that influences human life. The environment can color all human life activities, ranging from lifestyle, behavior, mindset, and even personality. In the human environment, life consists of various elements, which are factors that make up the environment, including society. Society is groups of various human individuals who interact with one another and have a specific purpose. The interaction between individuals results in kinship relationships as a means of communication to form a social community. At this time, the crime level has disturbed public peace and order. Community participation very significant in realizing public peace and order conditions. Besides, the role of community participation and obligations in realizing public peace and order condition is also stated in the 1945 Constitution of the Republic of Indonesia as citizens as set out in Section XII Article 30 Paragraph 1 and 2 (Republik Indonesia, 2002a):

1) Each citizen has the right and the duty to participate in the defense and security of the state.

2) The defense and security of the state are undertaken through a defense and security system that encompasses the entire population with TNI and POLRI as the main powers, and the population as the supporting power.

Relation to this matter based on Law Number 2/2002 concerning State Police of the Republic of Indonesia, whereas based on the considerations as meant in point b: "Whereas national security defense through the police functions that includes the defense of public orderliness and safety, law enforcement, protection, safeguard and services to public shall be conducted by the State Police of the Republic of Indonesia as the state's tool-assisted by society holding high the human rights" (Republik Indonesia, 2002b).

Community participation is one of the important functions in social life. Safe is a condition that is free from all forms of interference and obstacles. The word safe, in this understanding, contains 4 (four) basic meanings, namely: 1. Security, namely feeling free from physical and psychological disorders; 2. Surety, which is a feeling free from worries; 3. Safety, i.e., the feeling of being protected from all dangers; and 4. Peace, which is a feeling of inner peace. While the meaning of the word order is a condition in which the social unit, including the community members with all functions and positions, can play a role according to existing provisions.

Safe and order are the condition that is needed in support of the implementation of public peace and order and all community activities. Public peace and order condition is highly expected by the entire community to be realized, giving rise to calm and peace for every community and increasing motivation and enthusiasm for work. There is no fear due to the possibility of interference befall. Public peace and order are the responsibility of the whole community and the government, including the police as law enforcement officers. In its implementation, the police conduct efforts/actions manifested in police operations activities, both routine and specific.

Efforts are needed to convince the public to participate in public order, namely the communication between the government and the community, or vice versa. This situation will change people's attitudes and actions from apathy to support and to participate. This shows how big the role of government is in increasing community participation. Public participation helps each program's success according to each person's ability without sacrificing their interests. It is necessary to contribute in the form of ideas, critics, and voluntary opinions and be directly involved in running order in an area. There is socialization in every decision-making, and the community must also be involved in every decision-making. The community took the

Copyright ( $(2020$. Owned by Author(s), published by Society. This is an open-access article under the CC-BY-NC-SA license. https://doi.org/10.33019/society.v8i2.262 
initiative to start the social activities process to improve the situation and conditions that occur to create an order for a better direction.

In reality, according to initial observations, Imandi Village community participation was not good, and not fully aware of the importance of community participation in public order. Many are still more concerned with personal interests and less concerned about mutual peace.

The lack of community willingness and awareness to participate in direct involvement for peace in Imandi Village, East Dumoga Subdistrict, Bolaang Mongondow Regency becomes one of several caused factors. In the temporary suspicion, the main thing was caused by some village people who often gather and drink liquor so that trivial matters will become a big problem. When there are people in neighboring villages who come to visit will be the main target of a group of drunk people and disturbing people from the neighboring village so that people of the neighboring village feel unhappy with the community's treatment in the Imandi village. There is a defense between the villages who are angry over the mistreatment done by some Imandi village people caused a dispute between Imandi Village with Tambun Village. The incident made some people in the Imandi and Tambun villages feel insecure and made their livelihoods affected because they were busy taking care of the two villages' problems.

This study aims to analyze and describe the public participation level and the factors supporting and inhibiting public participation in maintaining peace and order in Imandi Village community.

\section{Literature Review}

\subsection{The Concept of Public Administration}

Administration based on etymology comes from Latin, consisting of "Ad" and "Ministrare", which means serving, helping, and fulfilling. Whereas in English, it becomes "Administration", and in Bahasa, it becomes "Administrasi" (Nawawi \& Martini, 1994).

Administration divided into two senses:

1) Administration in the strict sense, which is derived from the word "Administratie" (Dutch), which includes activities: notes, correspondence, light bookkeeping, typing, activities to compile information systematically, and records in writing to be documented, so that it is easy to find it when it will be used again, both separately and as an inseparable whole, and everything technical.

2) Administration in the broadest sense, which is derived from the word "Administration" (English):

a) According to Simon (1982), "Administration is the activity of groups that hold cooperation to complete common goals".

b) According to Gulick \& Urwick (2003), "Administration is concerned with completing what is being done, with the achievement of the goals set".

\subsection{The Concept of Participation}

According to Davis (1997), participation is a person's mental and emotional involvement in achieving goals and taking responsibility for them. In this definition, the key to thinking is mental and emotional involvement.

As stated in the guidelines for implementing a participatory approach compiled by the Department for International Development (DFID) (Monique, 2004), as follows:

1) Scope: all people or representatives of all groups affected by the results of a development project decision or process. 
2) Equality and partnership (Equal Partnership): basically, everyone has the skills, abilities, and initiatives and has the right to use these initiatives participated in every process to build dialogue.

3) Equality of Power (Sharing Power/Equal Powership): the various parties participated must balance the distribution of authority and power to avoid domination.

4) Equality of responsibility (Sharing Responsibility): various parties have clear responsibilities in each process because of the equality of authority (Sharing Power) and involvement in the decision-making process and subsequent steps.

5) Empowerment: the participation of various parties is inseparable from all the strengths and weaknesses of each party. Through active participation in each activity process, a process of learning and empowering one another occurs.

6) Cooperation: cooperation between various parties involved is needed to share strengths to reduce various weaknesses, especially those related to human resource capabilities.

\subsection{Community Participation}

Community participation is the participation of all community members in solving problems. In this case, the community itself is actively thinking, planning, implementing, and evaluating its public programs.

There are 6 (six) types of concepts regarding the interpretation of community participation, as follows:

1) Participation is a community's voluntary contribution to development projects or programs without participating in decision-makers.

2) Participation is an effort to make people more sensitive in increasing the willingness to accept and respond to development projects or programs.

3) Participation is an active process, which means that the person or group concerned takes the initiative and uses their freedom to do so.

4) Participation establishes a dialogue between local communities and staff in preparing, implementing, and monitoring projects/programs to obtain information about the local context and social impacts.

5) Participation is voluntary involvement by the community in self-determined changes.

6) Participation is a community's involvement in the development of themselves, their lives, and their environment.

It can be concluded that community participation is the community's involvement in implementing activities and in planning and developing the program's implementation, including enjoying the results of the program's implementation (Mantiri, 2018). Furthermore, community participation is simply the involvement of a person (individual) or a group of people voluntarily in activity starting from the planning process, implementing activities, and developing the activity or program.

In the Regulation of the Head of the State Police of the Republic of Indonesia Number 3 of 2015, Section I Article 3 point f (Kepolisian Negara Republik Indonesia, 2015): “Participation, namely the awareness of POLRI and community members, actively participates in various community activities to maintain a sense of security and order, provide information, suggestions, and input, and be active in the decision-making process to solve social security problems and not be vigilant".

The community has an active role in enhancing security and order by holding an environmental security system socialization that provides education and awareness to care

Copyright ( $(2020$. Owned by Author(s), published by Society. This is an open-access article under the CC-BY-NC-SA license. https://doi.org/10.33019/society.v8i2.262

764 
about order and environmental security. Every community needs peace and order to support work activities, education, and various other activities.

\section{Research Methodology}

This study uses qualitative research methods to use descriptive data in the form of written or oral words from people and observable behavior (Bogdan \& Taylor, 1975). In terms of other definitions, qualitative research utilizes open interviews to examine and understand individuals or groups of people's attitudes, views, feelings, and behavior. The approach used in this research is the descriptive approach. According to Whitney, the descriptive method is factfinding with proper interpretation (Whitney, 1960).

Subjects in this study are those related to community participation in public peace and order. Qualitative research can uses criterion-based selection based on the assumption that the subject is an actor in the study. Whereas in determining informants, the snowball sampling technique can be used to expand the research object.

Qualitative research is based more on the quality of information related to the proposed research theme. While in this study, the parties that can be used as a source of information are as follows:

1) East Dumoga Police Chief;

2) Imandi Village Government;

3) Community leaders of Imandi Village.

In each study, the researcher is the primary data collection tool. In other words, the researcher is a research instrument, namely, to collect data. Also in this study used interview guidelines, field notes, and reference books as other research instruments. Data collection must be systematic, directed, and purposeful so that the data collected has relevance to the research conducted. The data collection techniques used in this study are observation, interview, and documentation to obtain data.

In qualitative research, data analysis is carried out from the beginning and throughout the research process. In this study, qualitative data analysis was used. Miles \& Huberman (2007) stated that the qualitative data analysis activities were carried out interactively and continued continuously until completion so that the data was not saturated. Activities in analyzing data are: 1) data collection, 2) data reduction, 3) data presentation, and 4) conclusion.

\section{Results and Discussion}

\subsection{Community Participation}

According to Adi (2007), community participation identifies problems and potential in the community, selection, and decision-making about alternative solutions to deal with problems, implementing efforts to overcome problems, and community involvement in evaluating changes. According to Muluk (2010, p. 8-10), community participation consists of sub-systems, namely, 1) community participation activities, 2) community political education, 3) community participation awareness, 4) local organizations, 5) local elites, 6) support local government, 7) DPRD support, and 8) central government support.

Based on the interviews with several informants in Imandi Village concerning community participation in maintaining public peace and order, it was found that participation in public peace and order was used in the study of the community members' roles, both formal and informal. In the implementation of public peace and order, community participation is very much needed by the community. This concerns the economic, social, and cultural aspects on 
peace and public order that will not succeed without the community's active role, both their position as objects and subjects in the development in the regions. Participation is very important to be promoted to all actors involved in public peace and order. Participation does not mean only from the people, community, or the government, but participation must come from all parties.

\subsection{Implementation of Participation}

According to Iswantoro (1996), given the diversity of the community, who participated could be divided into four categories: 1) Local community (age, gender, occupation, income, and residence), 2) Community leaders (local/informal leaders), 3) Government personnel and 4) Foreign personnel (from outside). These categories may not all be suitable for all activities or programs in implementing public peace and order. However, combining these characteristics will help determine "who" participates in this activity's various stages. All stakeholders (community, government, non-governmental organizations/NGOs, and other institutions) must play an active role in carrying out activities or programs in implementing public peace and order in Imandi Village, East Dumoga Subdistrict, Bolaang Mongondow Regency.

Interview results from several informants found that leaders who could be role models were needed to motivate people to participate through mutual assistance activities. Village community leaders can be the main motivator of mutual assistance activities so that their participation is needed. So far, village leaders influence if they gain formal or informal legitimacy. The willingness and ability to participate comes from those concerned (residents or community groups), while the opportunity to participate comes from outsiders who provide opportunities. If there is a will, but there is no citizens' or groups' ability in a community, participation will not occur even if given opportunity from the state or government administrators. Likewise, suppose there are will and ability, but the state or government administrators give no space or opportunity for the citizens or groups of a community. In that case, it is also impossible for community participation to occur.

Implementation of community participation in maintaining public peace and order should make the community feel that it is an object of government policy and must be able to represent the community itself according to their interests. The embodiment of community participation can be done, either individually or in groups, spontaneous or organized, sustainably or momentarily, and in certain ways that can be done. Community participation needs to be developed so that citizens' or community groups' will and ability to maintain public peace and order through various forms of activities, such as thoughts, energy, time, expertise, funds or materials, and the results. Local institutions are thus a dominant factor in driving participation. Community participation can be encouraged or stimulated by the government or community leaders because their participation tends to be ineffective outside the institutional context. Because in rural areas, local institutions are very important factors in village development efforts (Milton \& Norman, 1984).

\subsection{Mutual Assistance in Public Peace and Order}

The enactment of Law Number 32 of 2004 is a manifestation of democracy through decentralization. Thus the consequence is regional autonomy. With regional autonomy, the regional government and DPRD are expected to make regional policies participatory-populist oriented (Republik Indonesia, 2004). Participatory-populist policies outlined in the form of regional regulations should guarantee justice in society (Arnstein, 1969). The policy should be community needs and in line with government policy and truly supported by the community,

Copyright ( $(2020$. Owned by Author(s), published by Society. This is an open-access article under the CC-BY-NC-SA license. https://doi.org/10.33019/society.v8i2.262 
thus creating a top-down and bottom-up mindset interconnected in terms of needs and will impact government policies that involve the community.

The purpose and objectives of regional autonomy are 1) improving services and improving community welfare; 2) development of democratic life; 3) better service distribution; 4) respect for local culture; 5) attention to the potential and diversity of the region. To respect local culture, the regional government of North Sulawesi Province raised Mutual Assistance (Mapalus) as a local culture through Governor North Sulawesi Regulation Number 8 of 2012 concerning establishing the Mapalus Forum for Public Security and Order.

According to North Sulawesi Governor Regulation Number 8 of 2012, Article 1 Clause 1, Mapalus (mutual assistance) for public security and order is the spirit of cooperation, gathering, and involving the security apparatus of the village or village government with the community to help each other and actively cooperate in finding the root of the problem, solving social problems, and find solutions to realize the public peace, security, and order for the implementation of security and order, government, and social programs in the village (Gubernur Sulawesi Utara, 2012).

The purpose of this forum's establishment is to provide guidance and increase public awareness to maintain order, security, and overcome natural disasters, and protect the safety of life, property from various threats both inside and outside (Article 2). This Mapalus forum for public security and order is a joint forum that collects and engages the village security apparatus with the community to create public peace, security, and order in the village (Article 4) (Gubernur Sulawesi Utara, 2012).

Interview results from several informants found that Mapalus forum for public security and order carried out the main tasks, functions, and roles, each following laws and regulations, carried out the training/empowerment of rural communities, sought and collected data/information about potential natural disasters, non-natural and social disasters as well as problems in the fields of ideology, politics, economy, social culture, and defense and security. Mapalus forum for public security and order reports data/information obtained related to problems in the community, monitor the implementation of development programs carried out by the government in the village, make efforts to resolve conflicts/legal problems in the community by prioritizing persuasive, deliberative and consensus efforts, and as a consultant for every problem faced by the community (Pangalila et al, 2019).

The Government of Imandi Village, East Dumoga Subdistrict, Bolaang Mongondow Regency, need to continue managing and fostering community members, especially in multicultural communities. This is done to prevent the disruption of public peace and order. On the other hand, a multicultural community structure can cause the complexity of social, cultural, religious, economic, and peace problems. To overcome the complexity of problems while preventing peace and society order disturbances due to different interests in multicultural community life, local governments certainly use a cultural approach (local wisdom), where the primary groups such as traditional, religious, and community leaders are actively involved, as well as local cultural values such as norms, traditions and customs are used as instruments in solving various problems of public peace and order that are triggered by religious, cultural, economic, regional origin, and other conflicts.

Mapalus for public peace and order policies effectively overcome peace and order problems because they use local traditions and customs, namely by involving the community. The need for community involvement in this matter is community leaders and religious leaders who are influential as mediators and facilitators in solving the community's public peace and order 
problems because they have the authority and respect, for their opinions and suggestions, by community members.

\subsection{Community Participation in Maintaining Public Peace and Order}

Interview results from several informants found that the participation of the Imandi Village community was still poorly implemented and therefore in maintaining village peace and order would be better if through individuals who are small units, which allows the realization of the role of groups, called solidarity, which in turn will greatly affect group members or community members in the implementation of public peace and order.

Community participation is the community's active involvement in drafting and making decisions process related to governance. Thus, the community's interests can be channeled to formulate policies to accommodate as many aspirations and interests of the community and get broad community support. Community participation can be grouped into 2 (two) types of participation, namely (1) Community participation arises because of the inability of the government or (2) pure community participation because they need something.

The presence and participation of citizens in public meeting forums, and their active involvement in contributing ideas and suggestions, show that government affairs are also their business and not merely bureaucratic matters as has happened so far. However, it must be admitted that it is not easy to include all levels of the community in a forum, at the same time, the proposed solution is to provide access to representatives from various walks of life to participate and voice the interests of the groups they represent and submit proposals and thoughts in public meeting forums such as the Mapalus Forum for Public Peace and Order.

The concrete manifestation of this principle is the formation of forums or public policymaking mechanisms that provide wider access to the community to participate and the provision of facilities in the form of training for those who represent the community to be able to formulate the problems they face, such as public peace and order issues, and able to find ways to prevent and solve the right problems through forums or public channels that exist. Thus public participation in safeguarding and maintaining public peace and order is the active involvement of a person or group of people (communities) to contribute consciously and voluntarily in maintaining and maintaining public peace and order of the community, starting from planning, implementation, supervision to the evaluation stage, and participation in the achievement of objectives to improve public peace and order.

\subsection{Factors Affecting Community Participation in Maintaining Public Peace and Order}

In this focus, it can be concluded that there are 4 (four) indicators, namely:

1) Public awareness in the form of participation creates peace and order

Only a part of the community consciously participates in promoting Mapalus culture. Still, others need feedback for them. Even though Mapalus, as Minahasa cultural values such as cooperation, help each other, a sense of kinship or togetherness and brotherhood has existed long ago. It is practiced in Minahasa likewise in maintaining public peace and order.

2) Local elites' role in forming participation

The role of local elites in forming participation still lacks. What exists and happens only because there is a charge of interest, religious leaders tend to participate. Community leaders in the structure of the Mapalus forum for public peace and order were formally included in the forum to be included. Still, in reality, they were not functioning.

Copyright (C 2020. Owned by Author(s), published by Society. This is an open-access article under the CC-BY-NC-SA license. https://doi.org/10.33019/society.v8i2.262 
3) Government Political Support

Political Support Members of the DPRD are almost never seen except during campaign times. Usually, they appear only during the campaign to win the people's voice but are almost never seen again. The legislative body has never been directly involved in Mapalus for public peace and order activities. The legislative body's role as part of the community representative has not carried out its political task in carrying out the budgeting function. Budget support at the regency level is completely absent and less supportive.

4) Barriers to community participation

It can be concluded that community participation's main obstacle is weak socialization and coordination from policymakers. Furthermore, the weak coordination between the Provincial Government and the Regency Government vertically. Moreover, community involvement is only on temporary matters. In this case, the role of the government as a policymaker is very weak and not optimal.

\section{Conclusion}

The Imandi Village community's participation is still not well implemented and, therefore, in maintaining public peace and order in the village. It will be better if involved individuals who are small units allow the realization of groups' role, called solidarity, which will greatly affect group members or community members in the implementation of public peace and order. Efforts to motivate people to participate through Mapalus activities need leaders who can be role models. Village community leaders can be the main motivator of Mapalus activities, so that the participation of the government is needed. Imandi Village, East Dumoga Subdistrict, Bolaang Mongondow Regency needs to continue managing and fostering community members, especially in multicultural communities. This is done to prevent the disruption of public peace and order.

\section{Acknowledgment}

The authors are grateful to express gratitude to those who have had the pleasure to cooperate during this study.

\section{Declaration of Conflicting Interests}

The authors have declared no potential conflicts of interest concerning the study, authorship, and/or publication of this article.

\section{References}

Adi. I. R. (2007). Intervensi Komunitas Pengembangan Masyarakat Sebagai Upaya Pemberdayaan Masyarakat. Jakarta, Indonesia : PT Rajagrafindo Persada.

Arnstein, S. R. (1969). A Ladder Of Citizen Participation. Journal of the American Institute of Planners, 35(4), 216-224. https:/ / doi.org/10.1080/01944366908977225

Bogdan, R., \& Taylor, S. J. (1975). Metodologi Penelitian Kualitatif. Bandung, Indonesia: Remadja Karya.

Davis, K. (1977). Human behavior at work: Organizational behavior. New York, United States:McGraw-Hill.

Gubernur Sulawesi Utara. (2012). Pembentukan Forum Mapalus Keamanan dan Ketertiban Masyarakat. 
Gulick, L., \& Urwick, L. (Eds.). (2003). Papers on the Science of Administration (Early Sociology of Management and Organizations) (1st ed., Vol. IV). London, United Kingdom: Routledge.

Iswantoro, H. (1996). Pendekatan partisipatif dalam pembinaan masyarakat desa hutan. Paper dipresentasikan di Lokakarya Bina Desa Hutan, Balikpapan.

Kepolisian Negara Republik Indonesia. (2015). Peraturan Kepala Kepolisian Negara Republik Indonesia Nomor 3 Tahun 2015 Tentang Pemolisian Masyarakat. Retrieved from https:/ /ntb.polri.go.id/binmas/wp-content/uploads/sites/25/2018/02/perkap-no-3thn-2015-ttg-pemolisian-masyarakat.pdf

Mantiri, J. (2018). The Impact of Public Participation Towards Waste Management In Tataaran Patar Village of South Tondano District. Jurnal Ilmiah Administrasi Publik, 4(1), 56-58. https://doi.org/10.21776/ub.jiap.2019.004.01.8

Miles, M., \& Huberman, A. (2007). Analisis Data Kualitatif Buku Sumber tentang MetodeMetode Baru. Jakarta, Indonesia: Universitas Indonesia.

Milton, E., \& Norman, T. (1984). Local Organizations: Intermediaries in Rural Development. Ithaca, New York: Cornel University.

Monique, S. (2004). Perencanaan Darat-Laut yang Terintegrasi dengan Menggunakan Informasi Spasial yang Partisipatif. Jakarta, Indonesia: Pradya Paramita.

Muluk, K. (2010). Menggugat Partisipasi Publik dalam Pemerintahan Daerah. Malang, Indonesia: Bayumedia Publishing.

Nawawi, H., \& Martini, M. (1994). Penelitian Terapan. Yogyakarta, Indonesia: Gajah Mada University Press.

Pangalila, T., Mantiri, J., \& Biringan, J. (2019). Nilai Moral yang Terkandung dalam Semboyan Torang Samua Basudara Sebagai Sumber Toleransi. Jurnal Moral Kemasyarakatan, 4(1), 26-31. https://doi.org/10.21067/jmk.v4i1.3425

Republik Indonesia. (2002a). Undang-Undang Dasar Negara Republik Indonesia Tahun 1945. Retrieved from https://www.dpr.go.id/jdih/uu1945

Republik Indonesia. (2002b). Undang-Undang Republik Indonesia Nomor 2 Tahun 2002 Tentang Kepolisian Negara Republik Indonesia. Retrieved from https://www.dpr.go.id/jdih/index/id/299

Republik Indonesia. (2004). Undang-Undang Republik Indonesia Nomor 32 Tahun 2004 Tentang Pemerintahan Daerah. Retrieved from https://www.dpr.go.id/jdih/index/id/33

Simon, H. A. (1982). Administrative Behavior: A Study of Decision-Making Processes in Administrative Organization (Translated ed.). Jakarta, Indonesia: PT Bina Aksara.

Whitney, F. L. (1960). The Elements of Research (Asian Eds.). Osaka, Japan: Overseas Book Co.

\section{About the Authors}

1. Jeane Mantiri obtained her Master's degree in Public Administration from Universitas Negeri Manado, Indonesia, in 2014. The Author is an Assistant Professor at the Department of Public Administration, Faculty of Social Science, Universitas Negeri Manado, Indonesia. E-Mail: jeanelitha@unima.ac.id 
2. Cyntia Maria Siwi obtained her Master's degree in Public Administration from Universitas Negeri Manado, Indonesia, in 2014. The Author is an Assistant Professor at the Department of Public Administration, Faculty of Law, Social Science, and Political Science, Universitas Terbuka, Indonesia.

E-Mail: $\underline{\text { mariasiwi@ecampus.ut.ac.id }}$ 